\title{
Uncoupling protein 1 of brown adipocytes, the only uncoupler: a historical perspective
}

\section{Daniel Ricquier *}

Institute Cochin, Paris Descartes University, Paris, France

Edited by:

Patrick Seale, University of

Pennsylvania, USA

\section{Reviewed by:}

Marta Letizia Hribal, University of

Catanzaro Magna Graecia, Italy

Carol Huang, University of Calgary,

Canada

\section{*Correspondence:}

Daniel Ricquier, Paris Descartes,

Institute Cochin, 24 Rue du Faubourg

Saint-Jacques, 75014 Paris Cedex,

France.

e-mail:daniel.ricquier@

parisdescartes.fr
Uncoupling protein 1 (UCP1), is a unique mitochondrial membranous protein devoted to adaptive thermogenesis, a specialized function performed by brown adipocytes. Whereas the family of mitochondrial metabolite carriers comprises 40 members, UCP1 is the only memberable to translocate protons through the inner membrane of brown adipocyte mitochondria. By this process, UCP1 uncouples respiration from ATP synthesis and therefore provokes energy dissipation in the form of heat while, also stimulating high levels of fatty acid oxidation. UCP1 homologs were identified but they are biochemically and physiologically different from UCP1. Thirty five years after its identification, UCP1 still appears as a fascinating component. The recent renewal of the interest in human brown adipose tissue makes UCP1 as a potential target for strategies of treatment of metabolic disorders.

Keywords: brown adipocyte, fatty acid, membranous carrier, mitochondria, proton transport, respiration coupling, thermogenesis, uncoupling

\section{INTRODUCTION}

FROM PHYSIOLOGICAL MEASUREMENTS OF THERMOGENESIS TO THE IDENTIFICATION OF UCP1

Basal thermogenesis results from the basal activity of many biochemical pathways including ATP-ases and futile cycles. Adaptive thermogenesis is regulated and occurs in particular conditions (cold exposure, arousing from hibernation, food intake...). This process involves the recruitment of different cell types and the activation of specific biochemical pathways. Any process that occurs without performing useful work, accumulating intermediates, or concentrating ions has an efficiency of zero from the standpoint of energy conservation or $100 \%$ for the purposes of thermogenesis (Nicholls and Locke, 1984). Although ATP-ases contribute, the largest part of heat production by cells probably comes from many metabolic pathways and in particular from oxidation of substrates.

In rodents or in newborns of some species, elegant in vivo studies in the 1960s established that brown fat depots were engaged in thermogenesis; this led to an increase in the temperature of the blood in brown fat which was rapidly distributed to heart, brain, kidney, and skeletal muscle (reviews in Nicholls and Locke, 1984; Cannon and Nedergaard, 1985, 2004; Himms-Hagen and Ricquier, 1998). The thermogenic activity of brown adipocytes was confirmed by microcalorimetric determinations of the heat output of excised tissue, isolated brown adipocytes, and isolated brown fat mitochondria (Nedergaard et al., 1977; Seydoux and Girardier, 1977; Ricquier et al., 1979). Physiological or pharmacological experiments established that the ability of animals (mainly rodents) to activate thermogenesis in response to cold exposure correlates with the amount of brown fat and to its activation by the sympathetic nervous system mediates and (Himms-Hagen, 1989).

Thermogenesis is dependent on oxygen consumption and therefore on the ability of cells to oxidize substrates in their mitochondria. Morphologically, brown adipocytes are very unique since they contain an extremely high number of mitochondria; these specialized mitochondria have a highly developed inner membrane, the membrane where the respiratory chain complexes are anchored. In other words, the morphology of brown adipocytes confers on these cells a very high capacity to oxidize substrates (Figure 1). Therefore, when heat is required (exposure to the cold, as an example), norepinephrine released by sympathetic nerves rapidly activates brown adipocytes resulting in fatty acid oxidation and heat production. Independently, Smith and Lindberg observed in 1967 that thermogenesis in brown adipose cells resulted from a weak coupling of respiration to ADP phosphorylation, leading to waste of oxidation energy as heat. Some years later, Nicholls and Ricquier showed the presence of a specific $32-\mathrm{kD}$ protein in the inner mitochondrial membrane of brown adipocytes (Figure 1) that could uncouple respiration to produce heat rather than ATP (see reviews in Nicholls and Locke, 1984; Cannon and Nedergaard, 2004; Nedergaard et al., 2005). This protein was later termed uncoupling protein UCP and renamed uncoupling protein 1 (UCP1) when UCP2 was identified (Fleury et al., 1997). The obvious thermogenic activity of UCP1 in mitochondria was clearly demonstrated by Kozak et al. (1994) observing the cold sensitive phenotype of the Ucp $1^{-1-}$ mouse (Enerbäck et al., 1997). UCP1 activity and regulation are reviewed below.

\section{UCP1: A SPECIFIC PROTON CARRIER UNCOUPLING RESPIRATION FROM ATP SYNTHESIS} UCP1 IS A RESPIRATION UNCOUPLER, SHUNTING THE NORMAL PROTON CIRCUIT AND IS PHYSIOLOGICALLY REGULATED

The physiological measurements of BAT thermogenic activity instigated the search for a mechanism unique to brown adipocyte mitochondria. The search for a respiration uncoupling mechanism, unique to these mitochondria came at a moment when Mitchell had proposed the - rather debated at that time - chemiosmotic theory; a theory explaining that the proton gradient and 

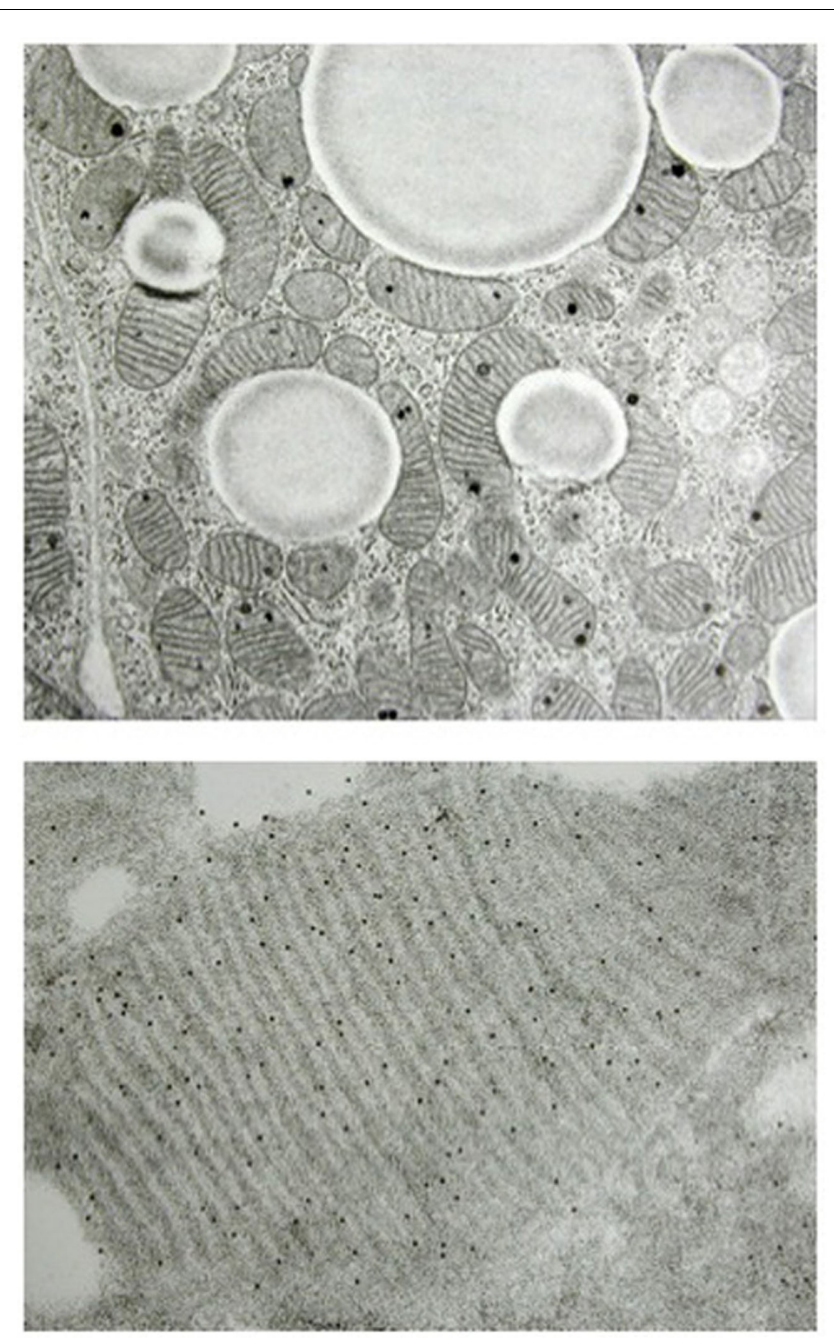

FIGURE 1 | Histology of brown adipocyte and presence of UCP1 in mitochondria. The cytosol of brown adipocytes is characterized by numerous mitochondria and lipid droplets (upper part). Magnification of a brown adipocyte mitochondrion showing parallel cristae and UCP1 detected using antibodies (black dots, lower part). (Figure kindly provided by Dr. Saverio Cinti, University of Ancona).

proton circuit through the inner membrane of mitochondria or chloroplasts, were governing ADP phosphorylation following respiration or exposure to light. According to Mitchell, oxidative phosphorylation is the process by which ADP phosphorylation by the mitochondrial ATP-synthase is coupled to mitochondrial oxygen consumption and to re-oxidation of reduced coenzymes via the proton electrochemical gradient generated by complexes I, III, and IV of respiratory chain. Oxygen then accepts electrons at the level of cytochrome-c-oxidase (complex IV) for conversion to water. Therefore, according to Mitchell, energy of the proton gradient $\left(\Delta \mu_{\mathrm{H}+}\right)$, or the so-called proton-motive force $\Delta \mathrm{p}$, is used to drive ATP synthesis by ATP-synthase. The proton gradient slows respiratory chain activity and facilitates ATP synthesis. The message here was that a proton circuit linking respiratory chain (protons out) and ATP-synthase (proton re-entry) operated such that oxygen consumption and ATP synthesis were tightly linked (Figure 2). Consequently, a proton leak in the inner mitochondrial membrane, distinct from the re-entry of protons via ATP-synthase, would lower the proton gradient and allow energy to be dissipated as heat. The reason for that is that down regulation of the proton gradient lowers the membrane potential which immediately activates the proton pumps and respiratory chain and provokes heat production since oxidation energy is not consumed by the ATP-synthase machinery. Actually, this is what happens when a chemical uncoupler is added to respiring liver or skeletal muscle mitochondria. Taken into consideration this postulate, Nicholls observed that isolated brown adipocyte mitochondria exhibit a very high and unique ion permeability in their inner membrane (review in Nicholls, 2006). This ion permeability, first detected as a chloride permeability, is a proton permeability strongly inhibited in presence of nucleotides, previously shown by Rafael and others to restore the respiratory control of brown adipocyte mitochondria (reviews in Cannon and Nedergaard, 2004; Nicholls, 2006). Photo-affinity labeling of hamster brown fat mitochondria with radioactive nucleotides was used by Heaton et al. (1978) to identify the uncoupling (proton transport) pathway as a 32$\mathrm{kD}$ membranous protein. These data were in agreement with the previous description of this protein, when such a protein was (i) described to be present in rat brown fat mitochondria membrane but absent in liver mitochondria, (ii) the only membrane protein to be significantly increased in brown fat mitochondria following cold-adaptation, and (iii), down regulated when cold-exposed animals returned to the warm (Ricquier and Kader, 1976). Therefore, UCP1 not only plays an important physiological role in Nature, it also occupies a unique position among the family of membranous mitochondrial porters driven by oxidative metabolism: it is the exception that proves the rule of chemi-osmotic theory (Garlid and Jaburek, 1998; Figure 2).

\section{UCP1 PROTON TRANSPORT ACTIVITY AND REGULATION}

Nicholls developed a methodology to determine the current/voltage relationship of the basal proton leak of mitochondria by titrating down succinate respiration with malonate, allowing to calculate $\mathrm{CmH}^{+}$, the proton conductance of the inner membrane of liver mitochondria in nanomole $\mathrm{H}^{+} / \mathrm{min}^{-1} / \mathrm{mg}^{-1}, \mathrm{mv}^{-1}$. Doing that with brown fat mitochondria, he found that the freshly prepared mitochondria had an enormous proton conductance and were incapable to maintain more than a few $\mathrm{mV}$ of proton-motive force whereas coupled mitochondria exhibit a membrane potential value close to $200 \mathrm{mV}$. It became clear that UCP1, when active, was acting as a proton translocator (Nicholls, 2006). When thermogenesis is not required, nucleotides bind UCP1 and inhibit its activity. In presence of inhibitory nucleotides, UCP1 has no residual proton conductance and is not leaky (Shabalina et al., 2010). From physiology physiology perspective, the search for a natural activator of UCP1 was logical. When thermogenesis is physiologically required, norepinephrine released by surrounding sympathetic fibers activates lipolysis which increases the level of free fatty acids in brown adipocyte mitochondria. The free fatty acids not only act as substrates for oxidation but also activate UCP1. The demonstration of the major ability of free fatty acids to activate UCP1 came from experiments where albumin 


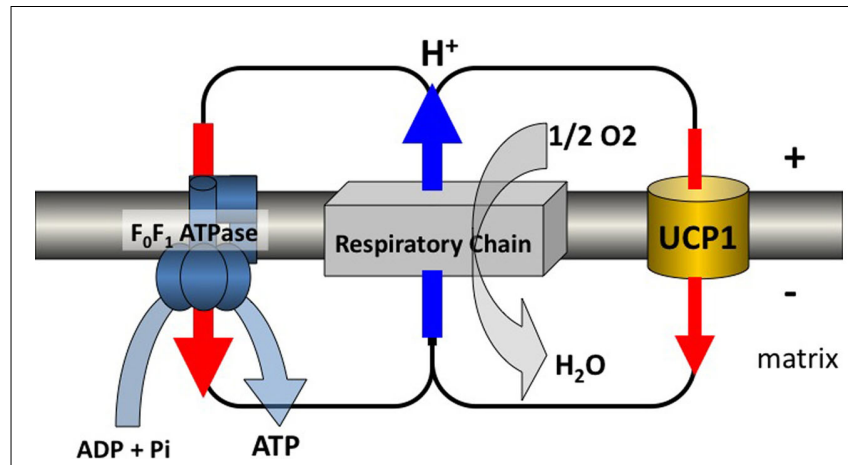

FIGURE 2 | Proton circuit. UCP1 is inserted in the mitochondrial inner membrane where, also present, is a multienzymatic complex called the respiratory chain made of complexes I to IV. The respiratory chain reoxidizes reduced coenzymes and electrons are driven to oxygen. This oxido-reduction step liberates energy which is used to generate an electrochemical gradient of protons across the inner membrane. This gradient is normally consumed by the ATP-synthase which phosphorylates ADP. UCP1 transports protons passively and makes possible a futile cycle of protons across the inner membrane leading to increased energy expenditure. This schema illustrates the situation encountered in brown adipocytes of mammals where a large amount of respiratory chains as well as a large amount of UCP1 are present. Activation of the futile cycling increases considerably energy expenditure and thus heat production by these thermogenic cells. In other cells where homologs of the UCP1 are expressed at much lower level, this pathway would represent a minor contributor to energy expenditure, but might be of importance to avoid oxidative damage (Figure kindly designed by Frédéric Bouillaud). for free fatty acids were added to isolated brown adipocytes cells and mitochondria. For example, in an elegant experiment, brown adipocyte mitochondria were slowly infused with palmitate to mimic lipolysis. During this procedure, the $\mathrm{CmH}^{+}$of UCP1 increased dramatically, the membrane potential decreased, and respiration rose sharply. (Nicholls and Locke, 1984; Ledesma et al., 2002; Cannon and Nedergaard, 2004; Nicholls, 2006). Comparing $w t$ and $U c p 1^{-1-}$ mice brown fat mitochondria and using a nonmetabolizable fatty acid analog, the Stockholm group confirmed the importance of UCP1 in thermogenesis and demonstrated that neither the ability to be metabolized, nor an innate uncoupling activity was a necessary property of UCP1 activators (Shabalina et al., 2008).

Other demonstrations of the proton transport activity of UCP1 were made by researchers who reconstituted its activity in liposomes (see an example in Figure 3). In such conditions, free fatty acids activate the proton translocating activity of UCP1 whereas nucleotides (GDP, GTP, ADP, ATP) inhibit it (Strieleman et al., 1985; Winkler and Klingenberg, 1994). According to these data, $\mathrm{UCP} 1$ is a purely $\mathrm{H}^{+}$translocating protein, the protons being translocated in a carrier-like fashion, instead of by a $\mathrm{H}^{+}$channel through the membrane. In other respects, there is still a debate whether fatty acids, (i) only activate proton transport (GonzálezBarroso et al., 1998; Ledesma et al., 2002; Mozo et al., 2006), (ii) participate as a prosthetic group that delivers protons to a site where they are translocated to the matrix, or (iii) are transported as anions by UCP1 as a part of a cycling mechanism completed with the translocation of the protonated form across the lipid

\section{assay of UCP1 $\mathrm{H}^{+}$transport in liposomes}

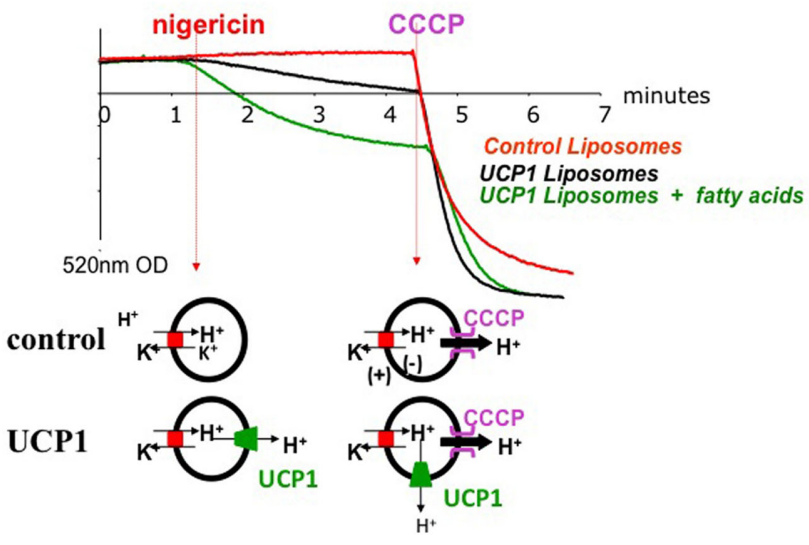

FIGURE 3 | Reconstitution of the proton transport activity of purified UCP1 in liposomes (Mozo et al., 2006). Membrane potential $(\Delta \Psi)$ is appreciated using a safranin probe sensitive to membrane potential and allowing a measurement of optical density at $520 \mathrm{~nm}$. In presence of nigericin, $\mathrm{H}^{+}$is exchanged against $\mathrm{K}^{+}\left(\mathrm{H}^{+}\right.$in, $\mathrm{K}^{+}$out), there is no charge exchange but a $\Delta \mathrm{pH}$ is generated. In liposomes containing UCP1, UCP1 dissipates this $\Delta \mathrm{pH}$ gradient and also increases $\Delta \Psi$ inducing the polarization of the membrane (and a decrease of O.D. signal). The slope of the decrease of the safranin signal is an assay of UCP1 protonophoric activity. Addition of fatty acids to liposome containing UCP1 markedly polarizes the membrane due to activation of the protonophoric activity of UCP1. Upon addition of CCCP, a strong protonophor, $\mathrm{H}^{+}$ions go out and positively polarize the liposome membrane on external side.

bilayer, with a net uptake of a proton (Skulachev, 1988; Garlid and Jaburek, 1998).

\section{UCP1 AA ACID SEQUENCE AND PREDICTED STRUCTURE}

The amino-acid sequence of UCP1 was determined following purification by Klingenberg (2010) and Aquila et al. (1985). It was also predicted from the sequencing of cloned cDNA (Bouillaud et al., 1985, 1986). Clearly, UCP1 is partly homologous to members of the anion mitochondrial carriers protein family (also referred to as the metabolite transporters of the mitochondrial inner membrane), including the ADP/ATP carrier and the phosphate carrier. Moreover, like the ADT/ATP carrier and mitochondrial carriers, UCP1 has a tripartite structure comprising three similar sequences of $\sim 100$ residues each. Hydropathy plot analysis predicted the existence of six membrane-spanning $\alpha$-helices (Aquila et al., 1985; Bouillaud et al., 1986). This prediction was supported by an immunological analysis of antigenic sites in UCP1 (Miroux et al., 1993). UCP1 structure has not been resolved yet but is probably close to the structure of the adenine nucleotide translocator (Pebay-Peyroula et al., 2003) and the structure of UCP2 recently identified (Berardi et al., 2011).

\section{UCP1 IS SPECIFIC FOR BROWN ADIPOCYTES AND IS VERY ABUNDANT}

The specific activity of UCP1 is unique to brown adipocytes. This was fully demonstrated in mice made null for $U c p 1$, which became hypothermic in a cold ambiance (Enerbäck et al., 1997; Nedergaard et al., 2001). It was also confirmed by recombinant 
expression of UCP1 in yeasts or mammalian cells (Casteilla et al., 1990; Bouillaud et al., 1994; González-Barroso et al., 1998). Many experimental approaches including UCP1 mRNA detection or UCP1 immunodetection, as well as the analysis of the activity of a reporter gene drived by $U c p 1$ promotor in transgenic mice, confirmed that $U c p 1$ expression is only observable in brown adipocyte (Cassard-Doulcier et al., 1998; Ricquier and Kozak, 2003).

An additional feature of UCP1 is that it is markedly abundant in brown adipocyte mitochondria where it comprises up to $8 \%$ of the total protein. The reason for such an amount is unknown but suggests that UCP1 molecular activity is rather weak.

\section{UCP1 GENE: SPECIFIC EXPRESSION IN BROWN ADIPOCYTES AND REGULATION OF TRANSCRIPTION CLONING OF CDNAS AND GENE, GENE ORGANIZATION IN RODENTS AND IN HUMANS, TRANSCRIPTIONAL REGULATION}

The question of transcriptional regulation of $U c p 1$ has two sides: its unique expression in brown adipocytes, and, the transcriptional activation by norepinephrine and other non-cell-autonomous factors like $\mathrm{T}_{3}$. In fact, it is not easy to list cis elements and trans-regulatory factors regulating, either the level of transcription of the gene, or the cell-specific transcription since these two mechanisms are probably controlled by the same factors. UCP1 biosynthesis is largely controlled at the level of transcription which is sharply activated within minutes after exposure of rodents to the cold (Ricquier et al., 1984, 1986; Ricquier and Kozak, 2003). The sympathetic activation of brown adipocytes and the subsequent and immediate rise in cAMP is the primary and main trigger of $U c p 1$ transcription, but other factors such as $\mathrm{T}_{3}$ (Silva and Rabelo, 1998) and retinoic acid (Alvarez et al., 1995; Larose et al., 1996; Rabelo et al., 1996; Gonzalez-Barroso et al., 2000a) are critical for a full physiological response (Gonzalez-Barroso et al., 2000b). The molecular mechanisms involved in the regulation of rodent and human UCP1 transcription have been partially elucidated and a critical 200-bp cis region (and more precisely the moiety of this region) having an enhancer activity, located a few $\mathrm{kb}$ upstream of the transcriptional start was identified (CassardDoulcier et al., 1993; Kozak et al., 1994; Gonzalez-Barroso et al., 2000a). This region is able to bind transcriptional factors such as CREB, CCAAT/enhancer binding proteins $\alpha$ and $\beta$, jun, Ets1, thyroid hormone receptors, retinoid X-receptor, and PPARs. Other important regions, in particular cAMP-response elements, were also identified outside of the enhancer region and in the promoter region (Cassard-Doulcier et al., 1994; Kozak et al., 1994; Yubero et al., 1994, 1998; Alvarez et al., 1995; Silva and Rabelo, 1998; Rim and Kozak, 2002; Xue et al., 2005). Xue et al. (2005) proposed that small variations in the levels of several transcriptional components of the $U c p 1$ enhanceosome interact synergistically to achieve large differences in $U c p 1$ expression. In addition to these transcription factors, the co-activator PGC- $1 \alpha$ also plays an important role (Puigserver et al., 1998).

\section{GENETIC STUDIES IN HUMAN COHORTS}

The human UCP1 gene was mapped to the long arm of chromosome 4 in $\mathrm{q} 31$ region (Cassard et al., 1990). A Bcl 1 polymorphic site was identified at bp-3826 upstream of the TATA box of the UCP 1 promoter in Bouchard's laboratory (Oppert et al., 1994). Several studies of association of this polymorphism were conducted and revealed that the UCP1 A-3826G polymorphism is not a major contributor to obesity development, however, the main observation was a significant association of this polymorphism with fat gain over time (Oppert et al., 1994; Gonzalez-Barroso et al., 2000b).

\section{THE NOVEL UCPS, UCP2, AND UCP3 ARE BIOCHEMICALLY AND PHYSIOLOGICALLY DISTINCT FROM UCP1}

UCP2 and UCP3, two Homologs of UCP1, were described in 1997 (Boss et al., 1997; Fleury et al., 1997; Vidal-Puig et al., 1997). Initially, the high level of amino-acid similarity with UCP1 (these new proteins display $57 \%$ identity with UCP1) as well as functional assays in yeast were in favor of an uncoupling activity (Fleury et al., 1997; Rial et al., 1999). However, a large number of studies based on physiological measurements of UCP2 or UCP3 expression (such as a marked up-regulation of these two UCPs in skeletal muscles of rodents and humans upon starvation Bevilacqua et al., 2005; Millet et al., 2007) and on analysis of mice null for $U c p 1$ or $U c p 2$, contradicted the first view (Boss et al., 2000; Ricquier and Bouillaud, 2000; Stuart et al., 2001; Rousset et al., 2004). Presently, it is difficult to consider UCP2 or UCP3 as membranous carriers able to uncouple respiration similarly to UCP1 (Nedergaard et al., 1999; Nedergaard and Cannon, 2003). UCP1 is present in a unique tissue the function of which is thermogenesis, whereas UCP2 is widely expressed in tissues and cells (gut, lung, brain, pancreatic islets, immune cells...) and UCP3 is present in skeletal muscles and brown adipose tissue. It appears that these other UCPs are metabolite transporters of the inner mitochondrial inner membrane and can limit the level of reactive oxygen species (Arsenijevic et al., 2000; Harper and Gerrits, 2004). UCP2 is able to inhibit glucose-induced insulin release (Zhang et al., 2001) and it has a transport activity directly or undirectly favoring glucose sparing and fatty acid oxidation (Pecqueur et al., 2008, 2009; Bouillaud, 2009).

\section{CONCLUSION AND PROSPECTIVES: SEARCH FOR ACTIVATORS OR INDUCERS OF UCP1, IDENTIFICATION OF COMPONENTS MIMICKING UCP1, INDUCTION OF THERMOGENIC BROWN ADIPOCYTES}

The brown adipocytes remain the cells uniquely able to rapidly burn fatty acids and dissipate oxidation energy as heat. Their activity is strictly dependant on their high content of mitochondria and above all on the presence of UCP1, a very particular membranous carrier, able to disrupt the respiratory-induced $\Delta \mu_{\mathrm{H}}^{+}$via a physiologically regulated proton transport activity. Therefore, these cells and UCP1 in particular, offer a chance to find compounds that increase fatty acid oxidation in obese patients and also in patients with metabolic syndrome.

Consequently, understanding the mechanisms which regulate transcription and expression of the human $U C P 1$ will facilitate the identification of molecules able to increase the levels of this protein in order to elevate energy expenditure in adult patients. Another approach will be to activate the UCP1 protein itself by searching for specific activators solely interacting with UCP1 (Rial et al., 2011). This is certainly a difficult aim, but since free fatty acids 
activate UCP1, modified fatty acids could be engineered. However, such new molecules should be totally specific for UCP1. Another strategy will be to identify chemical compounds able to induce a very slight uncoupling of respiration in tissues such as muscles. However, this later approach is very risky since induction of respiration uncoupling, even moderate, in cells other than brown adipocytes, may lower ATP synthesis and therefore be extremely deleterious. Remember that the use of classical chemical uncoupler, such as 2,4-dinitrophenol, caused serious illness in imprudent individuals and must be strictly banned (Grundlingh et al., 2011). Finally, an interesting approach would be to facilitate the emergence of new brown adipocytes from precursors present in skeletal

\section{REFERENCES}

Alvarez, R., de Andrés, J., Yubero, P., Viñas, O., Mampel, T., Iglesias, R., Giralt, M., and Villarroya, F. (1995). A novel regulatory pathway of brown fat thermogenesis. Retinoic acid is a transcriptional activator of the mitochondrial uncoupling protein gene. J. Biol. Chem. 270, 5666-5673.

Aquila, H., Link, T. A., and Klingenberg, M. (1985). The uncoupling protein from brown fat mitochondria is related to the mitochondrial ADP/ATP carrier. Analysis of sequence homologies and of folding of the protein in the membrane. EMBO J. 4, 2369-2376.

Arsenijevic, D., Onuma, H., Pecqueur, C., Raimbault, S., Manning, B. S., Miroux, B., Couplan, E., AlvesGuerra, M. C., Goubern, M., Surwit, R., Bouillaud, F., Richard, D., Collins, S., and Ricquier, D. (2000). Disruption of the uncoupling protein2 gene in mice reveals a role in immunity and reactive oxygen species production. Nat. Genet. 26, 435-439.

Berardi, M. J., Shih, W. M., Harrison, S. C., and Chou, J. J. (2011). Mitochondrial uncoupling protein 2 structure determined by NMR molecular fragment searching. Nature 476, 109-113.

Bevilacqua, L., Ramsey, J. J., Hagopian, K., Weindruch, R., and Harper, M. E. (2005). Long-term caloric restriction increases UCP3 content but decreases proton leak and reactive oxygen species production in rat skeletal muscle mitochondria. Am. J. Physiol. Endocrinol. Metab. 289, E429-E438.

Boss, O., Hagen, T., and Lowell, B. B. (2000). Uncoupling proteins 2 and 3 : potential regulators of mitochondrial energy metabolism. Diabetes 49 , 143-156.

Boss, O., Samec, S., Paoloni-Giacobino, A., Rossier, C., Dulloo, A., Seydoux, J., Muzzin, P., and Giacobino, J. P. (1997). Uncoupling protein-3: a new member of the mitochondrial carrier family with tissue-specific expression. FEBS Lett. 408, 39-42.

Bouillaud, F. (2009). UCP2, not a physiologically relevant uncoupler but a glucose sparing switch impacting ROS production and glucose sensing. Biochim. Biophys. Acta 1787, 377-383.

Bouillaud, F., Arechaga, I., Petit, P. X., Raimbault, S., Levi-Meyrueis, C., Casteilla, L., Laurent, M., Rial, E., and Ricquier, D. (1994). A sequence related to a DNA recognition element is essential for the inhibition by nucleotides of proton transport through the mitochondrial uncoupling protein. $E M B O J .13$, 1990-1997.

Bouillaud, F., Ricquier, D., Thibault, J., and Weissenbach, J. (1985). Molecular approach to thermogenesis in brown adipose tissue: cDNA cloning of the mitochondrial uncoupling protein. Proc. Natl. Acad. Sci. U.S.A. 82, 445-448.

Bouillaud, F., Weissenbach, J., and Ricquier, D. (1986). Complete cDNAderived aminoacid sequence of rat brown fat uncoupling protein. J. Biol. Chem. 261, 1487-1490.

Cannon, B., and Nedergaard, J. (1985). The biochemistry of an inefficient tissue: brown adipose tissue. Essays Biochem. 20, 110-164.

Cannon, B., and Nedergaard, J. (2004). Brown adipose tissue: function and physiological significance. Physiol. Rev. 84, 277-359.

Cassard, A. M., Bouillaud, F., Mattei, M. G., Hentz, E., Raimbault, S., Thomas, M., and Ricquier, D. (1990). Human uncoupling protein gene: structure, comparison with rat gene and assignment to the long arm of the chromosome 4. J. Cell. Biochem. 43, 255-264.

Cassard-Doulcier, A. M., Gelly, C., Bouillaud, F., and Ricquier, D. (1998). The 211-bp enhancer of the rat UCP-1 gene controls specific and regulated expression in the

muscles or in white adipose depots (Seale et al., 2007; Crisan et al., 2008).

\section{ACKNOWLEDGMENTS}

The author thanks Frédéric Bouillaud, Anne-Marie Cassard, Odette Champigny, Bruno Miroux, Louis Casteilla, Marianne Larose, Claire Pecqueur, Clotilde Alves-Guerra, Corinne LéviMeyrueis, Eduardo Rial, Maria del Mar Gonzalez-Barroso, Saverio Cinti, Francesc Villarroya, Denis Richard, and other colleagues for a long-term and friendly collaboration in the field. Our research is supported by the Centre National de la Recherche Scientifique and the Institut de la Santé et de la Recherche Médicale.

brown adipose tissue. Biochem. $J$. 333, 243-246.

Cassard-Doulcier, A. M., Gelly, C., Fox, N., Schrementi, J., Raimbault, S., Klaus, S., Forest, C., Bouillaud, F. and Ricquier, D. (1993). Tissuespecific and $\beta$-adrenergic regulation of the mitochondrial uncoupling protein gene - control by cis-acting elements in the $5^{\prime}$-flanking region. Mol. Endocrinol. 7, 497-506.

Cassard-Doulcier, A. M., Larose, M., Matamala, J. C., Champigny, O., Bouillaud, F., and Ricquier, D. (1994). In vitro interactions between nuclear proteins and uncoupling protein gene promoter reveal several putative trans-activating factors including Ets1, retinoid $\mathrm{X}$ receptor, thyroid hormone receptor and a CACCC box-binding protein. J. Biol. Chem. 269, 24335-24342.

Casteilla, L., Blondel, O., Klaus, S., Raimbault, S., Diolez, P., Moreau, F., Bouillaud, F., and Ricquier, D. (1990). Stable expression of functional mitochondrial uncoupling protein in Chinese hamster ovary cells. Proc. Natl. Acad. Sci. U.S.A. 87 5124-5128.

Crisan, M., Casteilla, L., Lehr, L. Carmona, M., Paoloni-Giacobino, A., Yap, S., Sun, B., Léger, B., Logar, A., Pénicaud, L., Schrauwen, P., Cameron-Smith, D., Russell, A. P., Péault, B., and Giacobino, J. P. (2008). A reservoir of brown adipocyte progenitors in human skeletal muscle. Stem Cells 26, 2425-3243.

Enerbäck, S., Jacobsson, A., Simpson, E. M., Guerra, C., Yamashita, H., Harper, M. E., and Kozak, L. P. (1997). Mice lacking mitochondrial uncoupling protein are coldsensitive but not obese. Nature 387 90-94.

Fleury, C., Neverova, M., Collins, S., Raimbault, S., Champigny, O., LeviMeyrueis, C., Bouillaud, F., Seldin, M. F., Surwit, R. S., Ricquier, D., and Warden, C. H. (1997). Uncoupling protein-2: a novel gene linked to obesity and hyperinsulinemia. Nat. Genet. 15, 269-272.

Garlid, K. D., and Jaburek, M. (1998). The mechanism of proton transport mediated by mitochondrial uncoupling proteins. FEBS Lett. 438, 10-14.

Gonzalez-Barroso, M., Pecqueur, C., Gelly, C., Sanchis, D., Alvez-Guerra, M. C., Bouillaud, F., Ricquier, D., and Cassard-Doulcier, A. M. (2000a). Transcriptional activation of the human UCP1 gene: synergism of retinoids, isoproterenol and thiazolidinedione is mediated by a multipartite response element. J. Biol. Chem. 275, 31722-31732.

Gonzalez-Barroso, M., Ricquier, D., and Cassard-Doulcier, A. M. (2000b). The human uncoupling protein-1 gene (UCP1): present status and perspectives in obesity research. Obes. Rev. 1, 61-72.

González-Barroso, M. M., Fleury, C., Bouillaud, F., Nicholls, D. G., and Rial, E. (1998). The uncoupling protein UCP1 does not increase the proton conductance of the inner mitochondrial membrane by functioning as a fatty acid anion transporter. $J$. Biol. Chem. 273, 15528-15532.

Grundlingh, J., Dargan, P. I., El-Zanfaly, M., and Wood, D. M. (2011). 2,4dinitrophenol (DNP): a weight loss agent with significant acute toxicity and risk of death. J. Med. Toxicol. 7, 205-212.

Harper, M. E., and Gerrits, M. F. (2004). Mitochondrial uncoupling proteins as potential targets for pharmacological agents. Curr. Opin. Pharmacol. 4, 603-607.

Heaton, G. M., Wagenvoord, R. J., Kemp, A., and Nicholls, D. G. (1978). Brown-adipose-tissue mitochondria: photoaffinity labelling of the regulatory site of energy dissipation. Eur. J. Biochem. 82, 515-521.

Himms-Hagen, J. (1989). Brown adipose tissue thermogenesis and obesity. Prog. Lipid Res. 28, 67-115. 
Himms-Hagen, J., and Ricquier, D. (1998). "Brown adipose tissue," in Handbook of Obesity, eds G. Bray, C. Bouchard, W. James (New York, Basel, Hong Kong: Marcel Dekker), 415-441.

Klingenberg, M. (2010). Wanderings in bioenergetics and biomembranes. Biochim. Biophys. Acta 1797, 579-594.

Kozak, U. C., Kopecky, J., Teisinger, J., Enerbäck, S., Boyer, B., and Kozak, L. P. (1994). An upstream enhancer regulating brown-fat-specific expression of the mitochondrial uncoupling protein gene. Mol. Cell Biol. 14, 59-67.

Larose, M., Cassard-Doulcier, A. M., Fleury, C., Serra, F., Champigny, O., Bouillaud, F., and Ricquier, D. (1996). Essential cis-acting elements in rat uncoupling protein gene are in the enhancer. Delineation of a complex element mediating the transcriptional activation by retinoic acid. J. Biol. Chem. 271, 31533-31542.

Ledesma, M., Garcià de Lacoba, M., and Rial, E. (2002). The mitochondrial uncoupling proteins. Genome Biol.3. PMID: 12537581.

Millet, L., Vidal, H., Andrealli, F., Larrouy, D., Riou, J. P., Ricquier, D., Laville, M., and Langin, D. (2007). Increased uncoupling protein-2 and uncoupling protein3 mRNA expression during fasting in obese and lean humans. J. Clin. Invest. 100, 2665-2670.

Miroux, B., Frossard, V., Raimbault, S., Ricquier, D., and Bouillaud, F. (1993). The topology of the brown adipose tissue mitochondrial uncoupling protein determined with antibodies against its antigenic sites revealed by a library of fusion proteins. EMBO J. 12, 3739-3745.

Mozo, J., Ferry, G., Masscheleyn, S., Miroux, B., Boutin, J. A., and Bouillaud, F. (2006). Assessment of a high-throughput screening methodology for the measurement of purified UCP1 uncoupling activity. Anal. Biochem. 15, 201-206.

Nedergaard, J., and Cannon, B. (2003). The "novel" "uncoupling" proteins UCP2 and UCP3: what do they really do? Pros and cons for suggested functions. Exp. Physiol. 88, 65-84.

Nedergaard, J., Cannon, B., and Lindberg, O. (1977). Microcalorimetry of isolated mammalian cells. Nature 267, 518-520.

Nedergaard, J., Golozoubova, V., Matthias, A., Asadi, A., Jacobsson, A., and Cannon, B. (2001). UCP1: the only protein able to mediate adaptive non-shivering thermogenesis and metabolic inefficiency. Biochim. Biophys. Acta 1504, 82-106.

Nedergaard, J., Matthias, A., Golozoubova, V., Jacobsson, A., and Cannon, B. (1999). UCP1: the original uncoupling - and perhaps the only one? New perspectives on UCP1, UCP2, and UCP3 in the light of the bioenergetics of the UCP1-ablated mice. J. Bioenerg. Biomembr. 31, 475-491.

Nedergaard, J., Ricquier, D., and Kozak, L. P. (2005). Uncoupling proteins: current status andtherapeutic prospects. EMBO Rep. 6, 9179-9121.

Nicholls, D. G. (2006). The physiological regulation of uncoupling proteins. Biochim. Biophys. Acta 1757, 459-466.

Nicholls, D. G., and Locke, R. M. (1984). Thermogenic mechanisms in brown fat. Physiol. Rev. 64, 1-64.

Oppert, J. M., Vohl, M. C., Chagnon, M., Dionne, F. T., Cassard-Doulcier, A. M., Ricquier, D., Pérusse, L., and Bouchard, C. (1994). DNA polymorphism in the uncoupling protein (UCP) gene and human body fat. Int. J. Obes. Relat. Metab. Disord. 18, 526-531.

Pebay-Peyroula, E., Dahout-Gonzalez, C., Kahn, R., Trézéguet, V., Lauquin, G. J., and Brandolin, G. (2003). Structure of mitochondrial ADP/ATP carrier in complex with carboxyatractyloside. Nature 426, 39-44.

Pecqueur, C., Alves-Guerra, C., Ricquier, D., and Bouillaud, F. (2009). UCP2, a metabolic sensor coupling glucose oxidation to mitochondrial metabolism? IUBMB Life 61, 762-767.

Pecqueur, C., Bui, T., Gelly, C., Hauchard, J., Barbot, C., Bouillaud, F., Ricquier, D., Miroux, B., and Thompson, C. B. (2008). Uncoupling protein-2 controls proliferation by promoting fatty acid oxidation and limiting glycolysis-derived pyruvate utilization. FASEB J. 22, 9-18.

Puigserver, P., Wu, Z., Park, C. W., Graves, R., Wright, M., and Spiegelman, B. M. (1998). A cold-inducible coactivator of nuclear receptors linked to adaptive thermogenesis. Cell 92, 829-839.

Rabelo, R., Reyes, C., Schifman, A., and Silva, J. E. (1996). A complex retinoic acid response element in the uncoupling protein gene defines a novel role for retinoids in thermogenesis. Endocrinology 137, 3488-3496.

Rial, E., Gonzalez-Barroso, M., Fleury, C., Iturrizaga, S., Sanchis, D., Jiménez-Jiménez, J., Ricquier, D., Goubern, M., and Bouillaud, F. (1999). Retinoids activate proton transport by the uncoupling proteins UCP1 and UCP2. EMBO J. $18,5827-5833$.

Rial, E., Rodríguez-Sánchez, L., Aller, P., Guisado, A., Mar González-Barroso, M., Gallardo-Vara, E., RedondoHorcajo, M., Castellanos, E., Fernández de la Pradilla, R., and Viso, A. (2011). Development of chromanes as novel inhibitors of the uncoupling proteins. Chem. Biol. 25, 264-274.

Ricquier, D., and Bouillaud, F. (2000). The uncoupling protein homologues: UCP1, UCP2, UCP3, StUCP and AtUCP. Biochem. J. 345 , 161-169.

Ricquier, D., Bouillaud, F., Toumelin, P., Mory, G., Bazin, R., Arch, J., and Pénicaud, L. (1986). Expression of uncoupling protein mRNA in thermogenic or weakly thermogenic brown adipose tissue. Evidence for a rapid $\beta$-adrenoceptor-mediated and transcriptionally regulated step during activation of thermogenesis. $J$. Biol. Chem. 261, 13905-13910.

Ricquier, D., Gaillard, J. C., and Turc, J. M. (1979). Microcalorimetry of isolated mitochondria from brown adipose tissue. Effect of guaninediphosphate. FEBS Lett. 99, 203-206.

Ricquier, D., and Kader, J. C. (1976) Mitochondrial protein alteration in active brown fat. A sodiumdodecylsulfate-polyacrylamide gel electrophoretic study. Biochem. Biophys. Res. Commun. 73, 577-583.

Ricquier, D., and Kozak, L. K. (2003). "Uncoupling proteins," in Handbook of Obesity, eds G. A. Bray and C. Bouchard (New York: Marcel Dekker Inc.), 539-558.

Ricquier, D., Mory, G., Bouillaud, F. Thibault, J., and Weissenbach, J. (1984). Rapid increase of mitochondrial uncoupling protein and its mRNA in stimulated brown adipose tissue. Use of a cDNA probe. FEBS Lett. 178, 240-244.

Rim, J. S., and Kozak, L. P. (2002). Regulatory motifs for CREB-binding protein and $\mathrm{Nfe} 2 \mathrm{l} 2$ transcription factors in the upstream enhancer of the mitochondrial uncoupling protein 1 gene. J. Biol. Chem. 277, 34589-34600

Rousset, S., Alves-Guerra, M. C., Mozo, J., Miroux, B., Cassard-Doulcier, A. M., Bouillaud, F., and Ricquier, D. (2004). The biology of mitochondrial uncoupling proteins. Diabetes 53(Suppl 1), S130-S135.

Seale, P., Kajimura, S., Yang, W., Chin, S., Rohas, L. M., Uldry, M., Tavernier, G., Langin, D., and Spiegelman, B. M. (2007). Transcriptional control of brown fat determination by PRDM16. Cell Metab. 6, 38-54.

Seydoux, J., and Girardier, L. (1977). Control of brown fat thermogenesis by the sympathetic nervous system. Experientia 33, 1128-1130.

Shabalina, I. G., Backlund, E. C., BarTana, J., Cannon, B., and Nedergaard, J. (2008). Within brownfat cells, UCP1-mediated fatty acidinduced uncoupling is independent of fatty acid metabolism. Biochim. Biophys. Acta 1777, 642-650.

Shabalina, I. G., Ost, M., Petrovic, N., Vrbacky, M., Nedergaard, J., and Cannon, B. (2010). Uncoupling protein-1 is not leaky. Biochim. Biophys. Acta 1797, 773-784.

Silva, J. E., and Rabelo, R. (1998). Regulation of the uncoupling protein gene expression. Eur. J. Endocrinol. 136, 51-64.

Skulachev, V. P. (1988). Uncoupling: new approaches to an old problem of bioenergetics. Biochim. Biophys. Acta 1363, 100-124.

Strieleman, P. J., Schalinske, K., and Shrago, E. (1985). Fatty acid activation of the reconstituted brown adipose tissue mitochondria uncoupling protein. J. Biol. Chem. 260, 3402-13405.

Stuart, J. A., Cadenas, S., Jekabsons, M. B., Roussel, D., and Brand, M. D. (2001). Mitochondrial proton leak and the uncoupling protein 1 homologues. Biochim. Biophys. Acta 1504, 144-158.

Vidal-Puig, A., Solanes, G., Grujic, D., Flier, J. S., and Lowell, B. B. (1997). UCP3: an uncoupling protein homologue expressed preferentially and abundantly in skeletal muscle and brown adipose tissue. Biochem. Biophys. Res. Commun. 1997, 79-82.

Winkler, E., and Klingenberg, M. (1994). Effect of fatty acids on $\mathrm{H}^{+}$ transport activity of the reconstituted uncoupling protein. J. Biol. Chem. 28, 2808-2515.

Xue, B., Coulter, A., Rim, J. S., Koza, R. A., and Kozak, L. P. (2005). Transcriptional synergy and the regulation of Ucpl during brown adipocyte induction in white fat depots. Mol. Cell Biol. 25, 8311-8322.

Yubero, P., Barberá, M. J., Alvarez, R., Viñas, O., Mampel, T., Iglesias, R., Villarroya, F., and Giralt, M. (1998). Dominant negative regulation by $\mathrm{c}$ Jun of transcription of the uncoupling protein-1 gene through a proximal cAMP-regulatory element: a mechanism for repressing basal and norepinephrine-induced expression of the gene before brown adipocyte differentiation. Mol. Endocrinol. 12, 1023-1037.

Yubero, P., Manchado, C., CassardDoulcier, A. M., Mampel, T., Vinas, 
O., Iglesias, R., Giralt, M., and Villarroya, F. (1994). CCAAT/enhancer binding proteins $\alpha$ and $\beta$ are transcriptional activators of the brown fat uncoupling protein gene promoter. Biochem. Biophys. Res. Commun. 198, 653-659.

Zhang, C. Y., Baffy, G., Perret, P., Krauss, S., Peroni, O., Grujic, D., Hagen, T., Vidal-Puig, A. J., Boss, O., Kim, Y. B., Zheng, X. X., Wheeler, M. B., Shulman, G. I., Chan, C. B., and Lowell, B. B. (2001). Uncoupling protein-2 negatively regulates insulin secretion and is a major link between obesity, $\beta$ cell dysfunction, and type 2 diabetes. Cell 105, 745-755.

Conflict of Interest Statement: The author declares that the research was conducted in the absence of any commercial or financial relationships that could be construed as a potential conflict of interest.

Received: 12 September 2011; paper pending published: 05 October 2011; accepted: 12 November 2011; published online: 28 December 2011.

Citation: Ricquier D (2011) Uncoupling protein 1 of brown adipocytes, the only uncoupler: a historical perspective. Front. Endocrin. 2:85. doi 10.3389/fendo.2011.00085
This article was submitted to Frontiers in Cellular Endocrinology, a specialty of Frontiers in Endocrinology.

Copyright () 2011 Ricquier. This is an open-access article distributed under the terms of the Creative Commons Attribution Non Commercial License, which permits non-commercial use, distribution, and reproduction in other forums, provided the original authors and source are credited. 